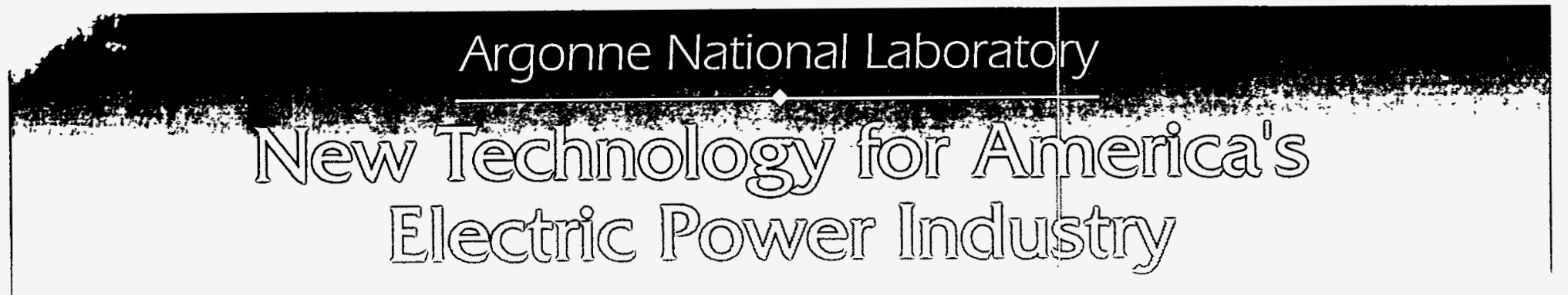

\title{
ANL/ES/CP_-85384
}

\section{Control of Air Toxics}

\section{Opportunity}

Passage of the Clean Air Act (CAA) Amendments of 1990 focused attention on the measurement and control of nearly 200 hazardous air pollutants ("air toxics") emitted by various industrial processes. Research is needed to measure process emissions, develop predictive emission factors, characterize the performance of existing control technologies, and identify new and improved control measures.

For more than 10 years, Argonne National Laboratory has supported the U.S. Department of Energy's Flue Gas Cleanup Program objective by developing new or improved environmental controls for industries that use fossil fuels. The goal is to help U.S. industries compete in an environmentally sound manner by providing costeffective control technologies. As new issues arise and emission limits are gradually reduced, continuing needs will arise for engineering improvements and research into new concepts that could lead to improved processes.

\section{Design Concept}

Argonne's pollutant emissions research has ranged from experiments in the basic chemistry of pollution-control systems, through laboratory-scale process development
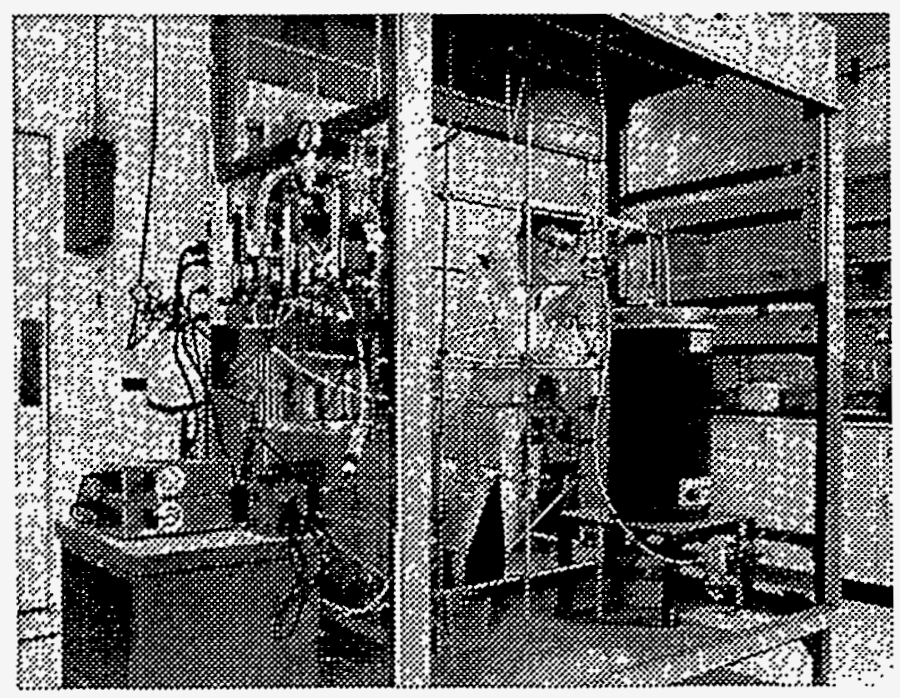

Lab Fixed-Bed Facility and testing, to pilot-scale field tests of several technologies. Whenever appropriate, the work has emphasized integrated or combined control systems as the best approach to technologies that offer low cost and good operating characteristics. The work on air toxics is currently divided into two components:
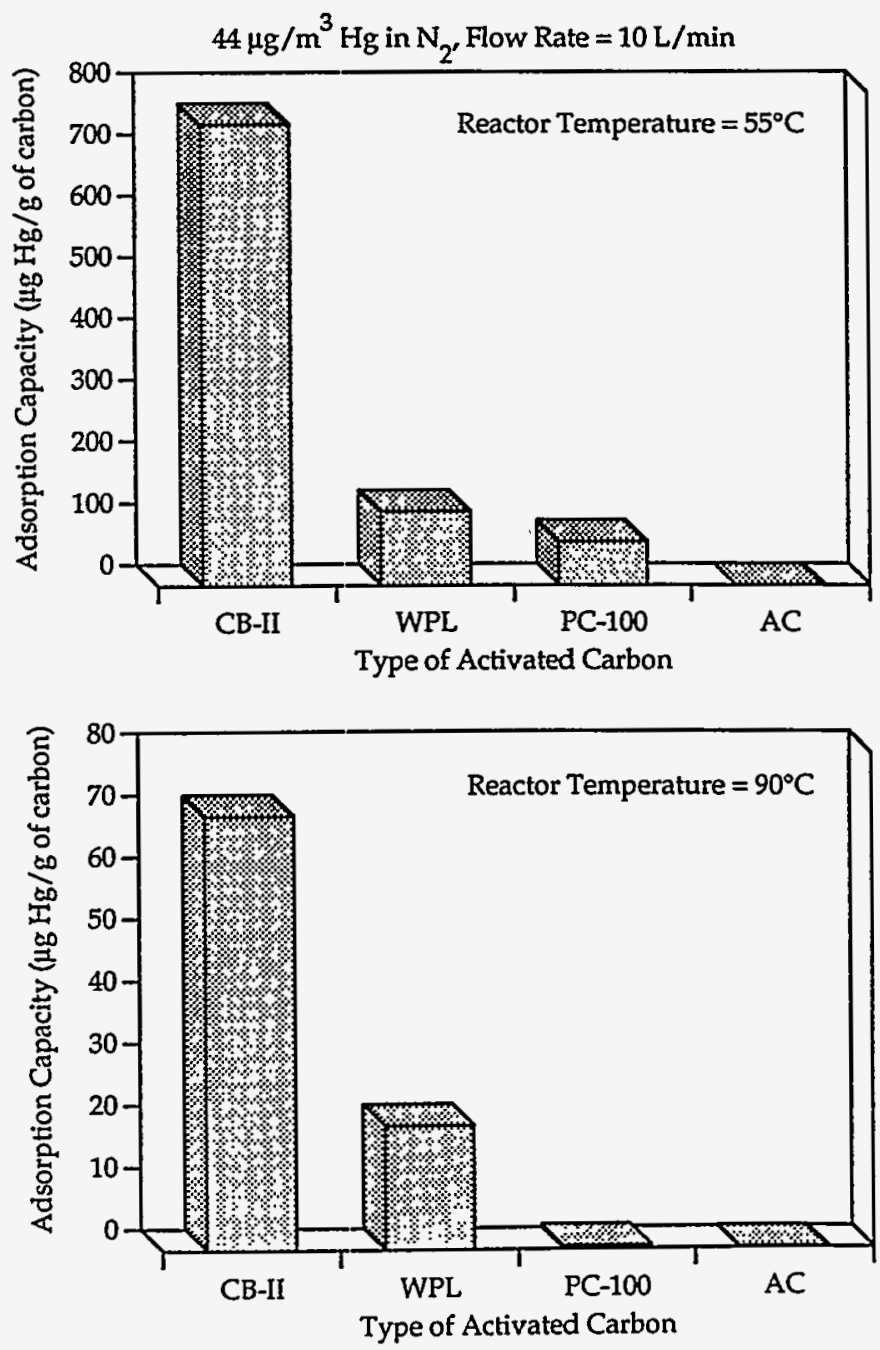

Mercury Adsorption Capacity at the Initiation of Breakthrough by Cornmercial Activated Carbons 


\section{DISCLAIMER}

Portions of this document may be illegible in electronic image products. Images are produced from the best available original document. 
- Investigating measures to improve the removal of mercury in existing pollution-control systems applied to coal combustion. The emphasis has been on evaluating activated carbons and other dry sorbents that could be injected into a gas stream or incorporated into a filter. In addition, modifications for wet scrubbers, including both chemical additives and various types of packing, are being evaluated.

- Developing sensors and control techniques for emissions found in the textile industry. Formaldehyde, for example, is known to be emitted in many processes, but the amounts are not well known, and appropriate control measures or minimization strategies have not been developed.

\section{Accomplishments}

Air-toxics research is a relatively new area; however, recent accomplishments include:

- Evaluation of the potential for mercury emissions from various types of coal-combustion systems and identification of promising control measures.

- Development of a new experimental research facility to evaluate dry sorbents for air-toxics control.

- Characterization of several types of plain and treated activated carbons for mercury control and comparative evaluations of proprietary sorbents supplied by industrial developers.

- Preliminary development of a new, low-cost solidstate sensor able to measure a wide variety of organic pollutants.

\section{Current Status}

Additional testing of dry sorbents for the capture of mercury and other air toxics will be conducted with the fixedbed reactor and the laboratory-scale spray-dryer system to develop viable process concepts for large-scale tests at industrial sites. Tests of wet scrubbing for removing mercury will continue to define the potential and limits for that technology. A test facility will be established to support research on sensors for various organic compounds and on controls for those compoundș. In parallel with these efforts, lests of gas-cleanup wastes and waste processing techniques will continue to ensure that land-based disposalcan be done safely.

\section{Fỡ More Information, Contact}

C. David Livengood

Energy Systems Division

Phone: (708) 252-3737

Argonne National Labcratory

9700 South Cass Avenue

Argonne, Illinois 60439
Fax: (708) 252-9281

\section{DISCLAIMER}

\begin{abstract}
This report was prepared as an account of work sponsored by an agency of the United States Government. Neither the United States Government nor any agency thereof, nor any of their employees, makes any warranty, express or implied, or assumes any legal liability or responsibility for the accuracy, completeness, or usefulness of any information, apparatus, product, or process disclosed, or represents that its use would not infringe privately owned rights. Reference herein to any specific commercial product, process, or service by trade name, trademark, manufacturer, or otherwise does not necessarily constitute or imply its endorsement, recommendation, or favoring by the United States Government or any agency thereof. The views and opinions of authors expressed herein do not necessarily state or reflest those of the United States Government or any agency thereof.
\end{abstract}

